\title{
Preparation and Photoluminescence Investigation of Organic-inorganic Hybrid Materials of Complex $\mathrm{Ag}_{2} \mathrm{ClO}_{5} \mathrm{~N}_{5} \mathrm{C}_{28} \mathrm{H}_{22}$
}

\author{
GU Chang Sheng ${ }^{1, ~ a ~, ~ H A O ~ X i a o ~ M i n ~}{ }^{1, b^{*}}, \mathrm{JI} \mathrm{Li} \mathrm{Li}^{2, \mathrm{c}}$, LI Yong ${ }^{1, \mathrm{~d}^{*}}$ and \\ SONG Wen Dong', e \\ ${ }^{1}$ Department of Applied Chemistry, Guangdong Ocean University, Zhanjiang 524088, People's \\ Republic of China \\ ${ }^{2}$ Innovation \& Application Institute, Zhejiang Ocean University, Zhoushan 316022, People's \\ Republic of China \\ aemail: hxmin2005@126.com, bemail: gcsheng1968@126.com, ${ }^{\mathrm{c} e m a i l: ~ j l l-g b @ 163 . c o m, ~}{ }^{\mathrm{d}} \mathrm{email}$ \\ yongli6808@126.com, ${ }^{\mathrm{e} e m a i l: ~ s w d 60 @ 163 . c o m ~}$
}

Keywords: organic-inorganic hybrid materials; luminescent property; 2-Chlorobenzeneacetic acid Abstract. One new organic-inorganic hybrid materials of complex $\mathrm{Ag}_{2} \mathrm{ClO}_{5} \mathrm{~N}_{5} \mathrm{C}_{28} \mathrm{H}_{22}$ (1) was synthesized by evaporation methods using 2-Chlorobenzeneacetic acid(2-CBAA), 4,4'-dipyridyl (4,4'-bipy), and $\mathrm{AgNO}_{3}$. And the complex was characterized by elemental analysis, FT-IR, thermogravimetrie analysis(TGA), XRD, X-ray single-crystal structure analysis and fluorescence properties have been studied. As a result, complex $\mathbf{1}$ are one-dimensional structure. Among others, $\operatorname{Ag}(\mathrm{I})$ ion is surrounded by two nitrogen atoms from two bipy ligands form an infinite chain, and adjacent Ag-bipy chains produce "rungs" of a ladder by silver ions contacts. Complex 1 emits the intensely luminescence with the fluorescence of $486 \mathrm{~nm}$ in a solid state at room temperature. CCDC: 1031206.

\section{Introduction}

The rational design and construction of organic-inorganic hybrid materials have received much attention in coordination chemistry because of their interesting molecular topologies and tremendous potential applications in luminescence, catalysis, molecular selection, gas storage, ion exchange, microelectronics and so on ${ }^{[1-5]}$. Generally speaking, the structural diversity of such organic-inorganic hybrid materials are dependent on many factors, such as metal ion, templating agents, metal-ligand ratio, $\mathrm{pH}$ value, counteranion, and number of coordination sites provided by organic ligand ${ }^{[6,7]}$. Considering the $\mathrm{d}^{10}$ closed-cell electronic configuration of silver ions, the preparations of silver organic-inorganic hybrid materials have attracted much attention ${ }^{[8]}$. Furthermore, silver ions have a flexible coordination number and irregular coordination spheres which may lead to the discovery of fascinating structures ${ }^{[9]}$. Chloro-benzene carboxylic acids have rich coordination modes such as terminal monodentate, chelating or bridging to more than one metal cation, and therefore they have been extensively employed in the preparation of complexes ${ }^{[10-12]}$. Heterocyclic nitrogen donors, such as 4,4'-bipyridine, have also been proved to be among the most important types of organic ligands for the design and construction of coordination polymers exhibiting remarkable properties for their excellent coordinating ability ${ }^{[13,14]}$. In this study, we introduced 2-Chlorobenzeneacetic acid(2-CBAA) with the nitrogen heterocyclic ligands in order to assemble one new organic-inorganic hybrid materials, namely, $\mathrm{Ag}_{2} \mathrm{ClO}_{5} \mathrm{~N}_{5} \mathrm{C}_{28} \mathrm{H}_{22}$ (1), which exhibit one-dimensional (1D) network structures.

\section{Physical Measurements}

The chemicals were purchased from commercial suppliers and used without further purification. Elemental analyses were performed on a CARLO ERBA 1106 analyzer. It shows the percentage of carbon, hydrogen and nitrogen of the complexes. The FT-IR spectra were recorded on a PerkinElmer Spectrum 100 FT-IR spectrometer using $\mathrm{KBr}$ pellet at a resolution of $0.5 \mathrm{~cm}^{-1}\left(400 \sim 4000 \mathrm{~cm}^{-1}\right)$. 
Thermogravimetry analyses were performed on an automatic simultaneous thermal analyzer (PE TG/DTA 6300) under a flow of $\mathrm{N}_{2}$ at a heating rate of $10^{\circ} \mathrm{C} \cdot \mathrm{min}^{-1}$ between ambient temperature and $800{ }^{\circ} \mathrm{C}$. Luminescence spectra for crystal solid samples were recorded at room temperature on a PERKIN ELMER LS 55 luminance meter. X-ray powdered diffraction pattern of the sample was recorded by an X-ray diffractometer (Rigaku D8) equipped with a graphite-monochromatic $\mathrm{Cu} K \alpha$ radiation.

\section{Experimental}

$\mathrm{Ag}_{2} \mathrm{ClO}_{5} \mathrm{~N}_{5} \mathrm{C}_{28} \mathrm{H}_{22}(\mathbf{1})$ : Complex 1 was prepared by the addition of stoichiometric amounts of silver nitrate (0.1699 g, $1 \mathrm{mmol}), 2-C B A A(0.3412 \mathrm{~g}, 2 \mathrm{mmol})$ and 4,4'-bipy (0.3124 g, $2 \mathrm{mmol})$ dissolved in a 2:1 methanol/water solution $(40 \mathrm{~mL})$ and the $\mathrm{pH}$ was adjusted to 7 with $0.15 \mathrm{~mol} / \mathrm{L}$ potassium hydroxide solution. After the mixture was stirred for $30 \mathrm{~min}$, the precipitate was dissolved in the aqueous solution of $\mathrm{NH}_{3}(25 \%)$ which was added drop by drop. Colorless crystals of the compound were obtained by evaporation of the solution for 15 days at room temperature in $52 \%$ yield (based on $\mathrm{Ag}$ ). Analysis calculated for $\mathrm{Ag}_{2} \mathrm{ClO}_{5} \mathrm{~N}_{5} \mathrm{C}_{28} \mathrm{H}_{22}(\%)$ : C, 44.27; H, 2.92; N, 9.22. Found (\%): C, 42.70; H, 2.90; N, 9.07.

\section{X-ray structure determination}

Single-crystal X-ray diffraction measurements were carried out on a Bruker SMART APEXII CCD diffractometer. The diffraction data were collected with $\operatorname{Mo} K \alpha$ radiation $(\lambda=0.071073 \mathrm{~nm})$. Empirical absorption corrections were carried out by using the SADABS program. The structures were solved by direct methods, and all of the non-hydrogen atoms were refined anisotropically on $F^{2}$ by the full-matrix least-squares technique using the SHELXL crystallographic software package. The hydrogen atoms were added theoretically, riding on the concerned atoms and refined with fixed thermal factors. The crystal structure data of complex 1 were listed in Table 1, the selected bond lengths and bond angles in Table 2 and hydrogen bond lengths and bond angles in Table 3.

Table 1 Crystal data and structure refinements of complex 1

\begin{tabular}{ll|ll}
\hline Empirical formula & $\mathrm{C}_{28} \mathrm{H}_{22} \mathrm{ClN}_{5} \mathrm{O}_{5} \mathrm{Ag}$ & $V / \AA^{3}$ & $2834.6(14)$ \\
Formula weight & 759.70 & $Z$ & 4 \\
Temperature / K & $295(2)$ & $\mu / \mathrm{mm}^{-1}$ & 1.523 \\
Size / mm & $0.30 \times 0.20 \times 0.18$ & $D_{\mathrm{c}} /\left(\mathrm{g} \cdot \mathrm{cm}^{-3}\right)$ & 1.780 \\
$\theta$ range for data collection / $\left.{ }^{\circ}\right)$ & 2.27 to 25.00 & $F(000)$ & 1504 \\
Crystal system & Monoclinic & Reflections collected & 7056 \\
Space group & $C c$ & Independent reflections & $3264(0.0514)$ \\
$a / \AA$ & $10.367(3)$ & Goodness of fit on $F^{2}$ & 1.055 \\
$b / \AA$ & $17.961(5)$ & $R_{1}, w R^{2}(I>2 \sigma(I))$ & $0.0567,0.1646$ \\
$c / \AA$ & $15.708(5)$ & $\mathrm{R}_{1}, w R_{2}($ all data $)$ & $0.0608,0.1725$ \\
$\beta /\left(^{\circ}\right)$ & $104.275(5)$ & $(\Delta \rho)_{\max },(\Delta \rho)_{\min } / \mathrm{e} . \AA^{3}$ & $0.823,-0.574$ \\
\hline
\end{tabular}

\section{Crystal structure}

The molecular structure of complex $\mathbf{1}$ is shown in Fig.1(a) and the selected bond distances and bond angles are listed in Table 2. Single-crystal X-ray diffraction analysis reveals that the asymmetric unit of 1 contains two $\mathrm{Ag}(\mathrm{I})$ cations, three coordinated 2-CBAA anions, two coordinated nitrate anions and two 4,4'-bipy ligands. The $\mathrm{Ag}(1)$ ions coordinate to two oxygen atoms from the 2-CBAA ligands and two nitrogen atoms from different bipy ligands, and the local coordination sphere around the $\mathrm{Ag}(1)$ ions can be described as a similar "wedge" shaped with a $\mathrm{AgO}_{2} \mathrm{~N}_{2}$ chromophore $\left(\mathrm{O}(1)-\mathrm{Ag}(2)-\mathrm{O}(2)=55.2(2)^{\mathrm{o}}\right.$ and $\left.\mathrm{N}(3)^{\mathrm{i}}-\mathrm{Ag}(1)-\mathrm{N}(4)=164.9(5)^{\circ}\right)$. The $\operatorname{Ag}(1)-\mathrm{N}$ and $\operatorname{Ag}(1)-\mathrm{O}$ 
distances fall in the range of $2.175(2) \sim 2.736(2) \AA$. Moreover, the silver ions $(\operatorname{Ag}(2)) \operatorname{are}$ five-coordinated by two different bipy $\mathrm{N}$ atoms, two $\mathrm{O}$ atoms of nitrates and one carboxylate $\mathrm{O}$ atom from 2-CBAA ligands, and the local coordination sphere around the $\mathrm{Ag}(2)$ ion can be described as a distorted square pyramid with a $\mathrm{AgO}_{3} \mathrm{~N}_{2}$ chromophore. Atoms $\mathrm{O}(1), \mathrm{O}(4), \mathrm{N}(2)$ and $\mathrm{N}(1)^{\mathrm{ii}}$ define the equatorial plane, while nitrate $\mathrm{O}(3)$ atom occupies the apical site $\left(\mathrm{O}(1)-\mathrm{Ag}(2)-\mathrm{O}(4)=161.30(3)^{\circ}\right.$ and $\left.\mathrm{N}(2)-\mathrm{Ag}(2)-\mathrm{N}(1)^{\mathrm{ii}}=168.1(5)^{\circ}\right)$. The $\mathrm{Ag}(2)-\mathrm{O}$ and $\mathrm{Ag}(2)-\mathrm{N}$ distances are in the range of 2.146(2) 2.869(2) $\AA$. The 2-CBAA ligand is connected to two $\mathrm{Ag}(\mathrm{I})$ ions through deprotonated carboxylate groups with $\eta_{3}: \mu_{2}$ coordination modes (chelating/bridging bidentate fashion). The dihedral angle between two pyridine ring planes of bipy ligand is $24.3(3)^{\circ}(\mathrm{N}(1)$ and $\mathrm{N}(2)$ atoms of pyridine ring) and $26.1(3)^{\circ}(\mathrm{N}(3)$ and $\mathrm{N}(4)$ atoms of pyridine ring).

All the $\mathrm{Ag}(\mathrm{I})$ ions are surrounded by two nitrogen atoms from two bipy ligands form an infinite chain. The adjacent Ag-bipy chains produce "rungs" of a ladder by $\operatorname{Ag}(1) \cdots \operatorname{Ag}(2)$ interactions (distances

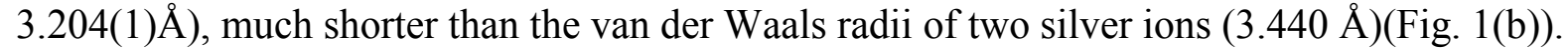
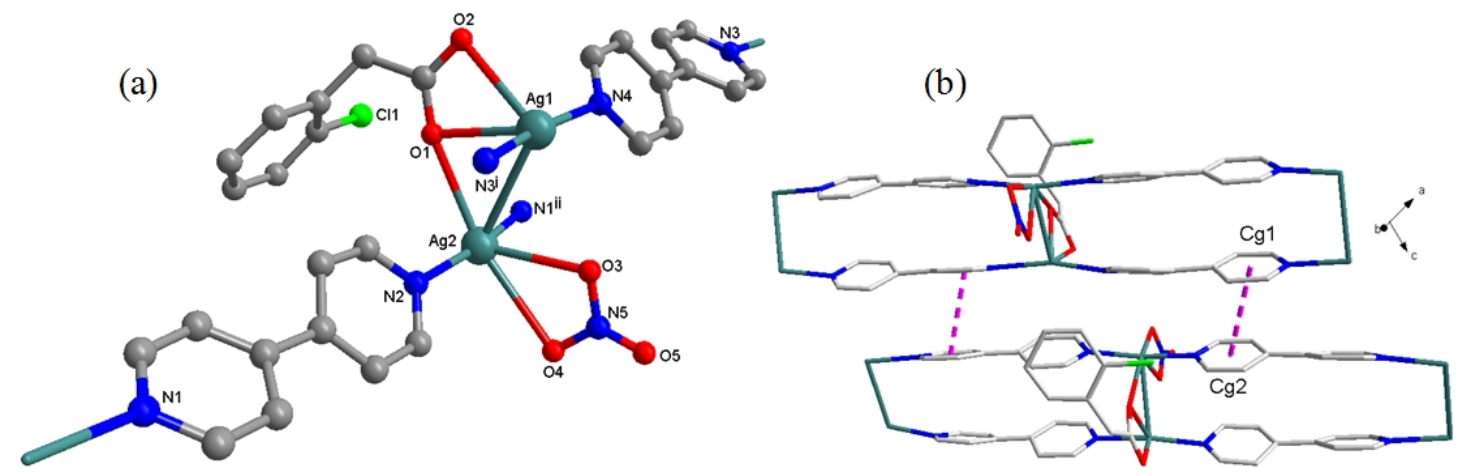

Fig.1 (a) Molecular structure (Symmetry codes: ${ }^{\mathrm{i}} \mathrm{x}-1,-\mathrm{y}+1, \mathrm{z}-1 / 2 ;{ }^{\mathrm{ii}} \mathrm{x}+1,-\mathrm{y}+1, \mathrm{z}+1 / 2$ ) and (b) $2-D$ structure of complex 1

Tabulation 2 Concernment bond lengths $(\AA)$ and bond angles $\left(^{\circ}\right)$

\begin{tabular}{llllll}
\hline Bond & Dist. & Bond & Dist. & Bond & Dist. \\
\hline $\operatorname{Ag}(1)-\mathrm{N}(4)$ & $2.175(2)$ & $\operatorname{Ag}(1)-\mathrm{N}(3)^{\mathrm{i}}$ & $2.195(1)$ & $\operatorname{Ag}(1)-\mathrm{O}(1)$ & $2.581(9)$ \\
$\operatorname{Ag}(1)-\mathrm{O}(2)$ & $2.666(2)$ & $\operatorname{Ag}(2)-\mathrm{O}(1)$ & $2.736(2)$ & $\operatorname{Ag}(2)-\mathrm{O}(4)$ & $2.869(2)$ \\
$\operatorname{Ag}(2)-\mathrm{O}(3)$ & $2.710(2)$ & $\operatorname{Ag}(1)-\operatorname{Ag}(2)$ & $3.204(1)$ & $\operatorname{Ag}(2)-\mathrm{N}(2)$ & $2.146(2)$ \\
$\operatorname{Ag}(2)-\mathrm{N}(1)^{\mathrm{ii}}$ & $2.174(2)$ & $\mathrm{N}(1)-\operatorname{Ag}(2)^{\mathrm{i}}$ & $2.174(2)$ & $\mathrm{N}(3)-\operatorname{Ag}(1)^{\mathrm{ii}}$ & $2.195(2)$ \\
$\mathrm{N}(4)-\operatorname{Ag}(1)-\mathrm{N}(3)^{\mathrm{i}}$ & $164.9(5)$ & $\mathrm{N}(4)-\operatorname{Ag}(1)-\mathrm{O}(1)$ & $108.3(4)$ & $\mathrm{N}(3)^{\mathrm{i}}-\operatorname{Ag}(1)-\mathrm{O}(1)$ & $86.8(4)$ \\
$\mathrm{N}(4)-\operatorname{Ag}(1)-\operatorname{Ag}(2)$ & $101.2(3)$ & $\mathrm{N}(3)^{\mathrm{i}}-\operatorname{Ag}(1)-\operatorname{Ag}(2)$ & $87.1(4)$ & $\mathrm{O}(1)-\operatorname{Ag}(1)-\operatorname{Ag}(2)$ & $55.2(2)$ \\
$\mathrm{N}(2)-\operatorname{Ag}(2)-\mathrm{N}(1)^{\mathrm{ii}}$ & $168.1(5)$ & $\mathrm{O}(2)-\operatorname{Ag}(2)-\mathrm{O}(4)$ & $161.3(3)$ & $\mathrm{O}(3)-\operatorname{Ag}(2)-\operatorname{Ag}(4)$ & $44.8(3)$ \\
\hline Symmetry code: ${ }^{\mathrm{i}} \mathrm{x}-1,-\mathrm{y}+1, \mathrm{z}-1 / 2$ & ${ }^{\mathrm{ii}} \mathrm{x}+1,-\mathrm{y}+1, \mathrm{z}+1 / 2$ & & &
\end{tabular}

The adjacent $\mathrm{Ag} \cdots \mathrm{Ag}$ distances of a ladder are 11.380 $\mathrm{A}(\mathrm{Ag} 1 \cdots \mathrm{Ag} 1)$ and $11.388 \AA(\mathrm{Ag} 2 \cdots \mathrm{Ag} 2)$. The 2- $D$ layer structure in complex 1 is further linked through $\pi^{\cdots} \pi$ interaction $(\mathrm{Cg} 1 \cdots \mathrm{Cg} 2=3.606 \AA$, the centroids $\mathrm{Cg} 1$ are made up of atoms $\mathrm{N}(3), \mathrm{C}(24), \mathrm{C}(25), \mathrm{C}(26), \mathrm{C}(27)$ and $\mathrm{C}(28)$. Moreover, the centroids $\mathrm{Cg} 2$ are composed of atoms $\mathrm{N}(1), \mathrm{C}(9), \mathrm{C}(10), \mathrm{C}(11), \mathrm{C}(12)$ and $\mathrm{C}(13))$. With the help of intermolecular interactions adjacent polymeric sheets are assembled to form a supramolecular 3- $D$ network structure.

Tabulation 3 Hydrogen bond $\left(\mathrm{H}^{\cdots} \mathrm{A}\right) / \AA$ ) and bond angles $\left({ }^{\circ}\right)$

\begin{tabular}{lcccc}
\hline $\mathrm{D}-\mathrm{H}^{\cdots} \mathrm{A}$ & $\mathrm{d}(\mathrm{D}-\mathrm{H})$ & $\mathrm{d}\left(\mathrm{H}^{\cdots} \mathrm{A}\right)$ & $\mathrm{d}(\mathrm{D} \cdots \mathrm{A})$ & $<($ DHA $)$ \\
$\mathrm{C}(2)-\mathrm{H}(2 \mathrm{~B}) \cdots \mathrm{Cl}(1)$ & 0.97 & 2.58 & $3.008(2)$ & 107.1 \\
$\mathrm{C}(17)-\mathrm{H}(17) \cdots \mathrm{O}(1)$ & 0.93 & 2.49 & $3.212(1)$ & 134.4 \\
$\mathrm{C}(21)-\mathrm{H}(21) \cdots \mathrm{O}(2)$ & 0.93 & 2.55 & $3.288(2)$ & 137.0 \\
$\mathrm{C}(10)-\mathrm{H}(10) \cdots \mathrm{O}(1)$ & 0.93 & 2.55 & $3.250(2)$ & 132.1 \\
\hline
\end{tabular}

Symmetry code: ${ }^{1} \mathrm{x}-1,-\mathrm{y}+1, \mathrm{z}-1 / 2$ 


\section{IR spectrum and Thermal analysis}

The asymmetric $v_{a s}\left(\mathrm{COO}^{-}\right)$and symmetrical $v_{s}\left(\mathrm{COO}^{-}\right)$appear in 1601,1477 and $1375 \mathrm{~cm}^{-1}$ of complex 1. The two values of $\Delta\left(\mathrm{COO}^{-}\right)$suggest the presence of two different coordinated modes of the carboxylate groups ${ }^{[15]}$. Meanwhile, the bands at $1532 \mathrm{~cm}^{-1}$ are assigned to the stretching vibration of $-\mathrm{N}=\mathrm{C}$ - of pyridyl in complex $\mathbf{1}$, respectively. In addition, the absorptions at 1216, 1067, 803 and $743 \mathrm{~cm}^{-1}$ in complex 1 belong to the absorption band of $\mathrm{NO}_{3}{ }^{-}$groups(Fig. 2) ${ }^{[16]}$.

In complex 1, the first corresponding to the escape of one nitrate anion is observed from 30 to $175^{\circ} \mathrm{C}($ Obsd. $8.10 \%$, Calcd. 8.16\%). The second corresponding to the departure of 2-CBAA and 4,4'-bipy ligand is observed from 176 to $652^{\circ} \mathrm{C}$ (Obsd. $62.72 \%$, Calcd. 63.57\%) in complex 1. The final decomposition products by further heating complex $\mathbf{1}$ are characterized to be metallic silver, with a total weight loss of $29.36 \%$ (Calcd. $28.43 \%$ (Fig. 3).

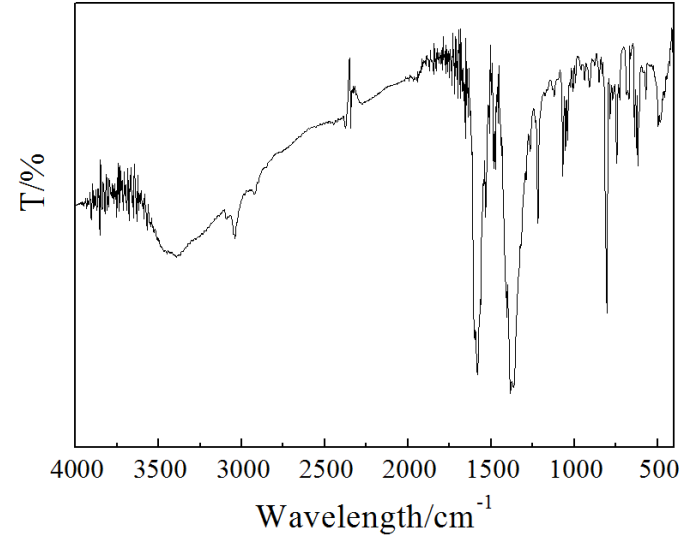

Fig.2 IR for complex 1

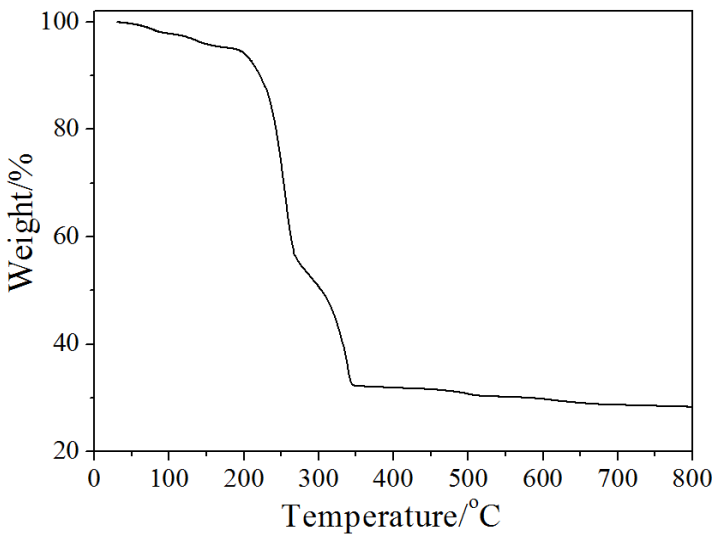

Fig.3 TG for complex 1

\section{X-ray powder diffraction and Luminescent Property}

As shown, the peak positions of the experimental patterns are in agreement with the simulated ones from single-crystal X-ray diffraction, which clearly demonstrates good purity of complex $\mathbf{1}$. There are a few unindexed diffraction differences between the measured and simulated patterns, which may be related to the different orientations of the crystals in the powdered samples(in Fig.4, black: simulation of single crystal; red: solid samples ).

In this study, fluorescent property of compound $\mathbf{1}$ has been investigated in the solid state. Two emission peaks at about $389 \mathrm{~nm}\left(\lambda_{\mathrm{ex}}=310 \mathrm{~nm}\right)$ and $421 \mathrm{~nm}\left(\lambda_{\mathrm{ex}}=343 \mathrm{~nm}\right)$ were observed for free 2-CBAA and 4,4'-bipy ligands, respectively. On complexation of these ligands with $\mathrm{Ag}(\mathrm{I})$ atoms, strong fluorescence with emission peak at about $486 \mathrm{~nm}\left(\lambda_{\mathrm{ex}}=287 \mathrm{~nm}\right)$ for the compound is observed at room temperature, while the emissions arising from the free ligands are not observed (Fig. 5). The absence of ligand-based emission suggests energy transfer from the ligands to the $\mathrm{Ag}(\mathrm{I})$ atoms during photoluminescence. Therefore, the photoluminescence can probably be assigned to the ligand-to-ligand charge-transfer transitions ${ }^{[17]}$. 


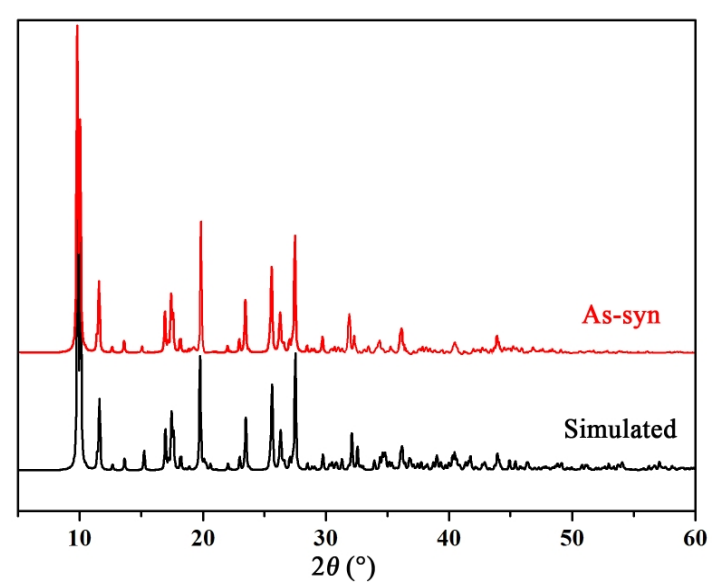

Fig.4 XRD for complex 1

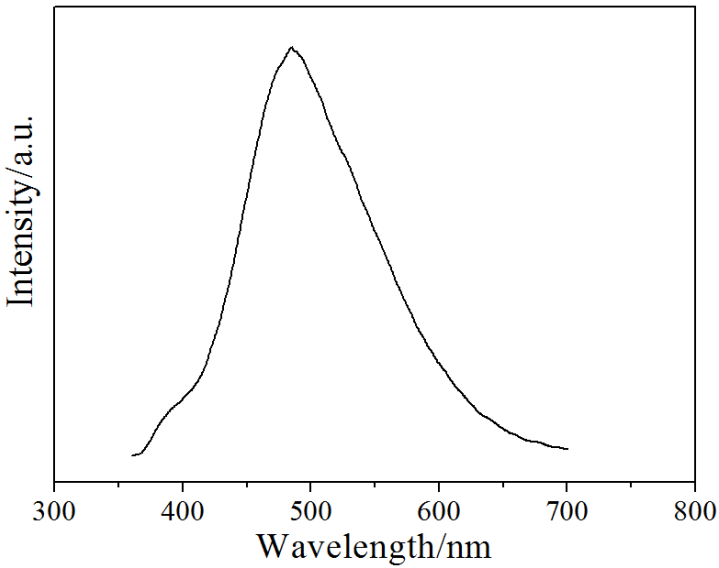

Fig.5 Pphotoluminescent spectrum for complex 1

\section{Summary}

The complex of $\mathrm{Ag}_{2} \mathrm{ClO}_{5} \mathrm{~N}_{5} \mathrm{C}_{28} \mathrm{H}_{22}$ (1), was synthesized and characterized. In complex 1, the Ag-bipy chains are linked into "rungs" of a ladder by silver(I) ion contacts. Complex 1 emits the intense luminescence with the fluorescence of $486 \mathrm{~nm}$ in the solid state at room temperature.

\section{Acknowledgment}

This work was supported by the Guangdong Science and Technology Department (No. S2012020011054 and 2011B090400415) and the Zhanjiang Municipality (No. 2011C3108001) projects.

\section{References}

[1]R.R.Yun, Z.Y. Lu, Y. Pan, X.Z. You, J.F. Bai, Formation of a metal-organic framework with high surface area and gas uptake by breaking edges off truncated cuboctahedral cages, Angew. Chem. Int. Ed. 52(2013)11282-11285.

[2]Y.J. Cui, Y.F. Yue, G.D. Qian, B.L. Chen, Luminescent functional metal-organic frameworks, Chem. Rev. 112(2012)1126-1162.

[3]X.M. Hao, C.S. Gu, S.Y. Han, Y.L. Miao, Y. Li, W.D. Song, Syntheses and crystal structures of $\mathrm{Cd}$ (II) and $\mathrm{Ni}$ (II) complexes containing flexible sulfide and nitrogen heterocyclic ligands, Chin. J. Struct. Chem. 34(2015)408-416.

[4]Y.J. Cui, Y.F. Yue, G.D. Qian, B.L. Chen, Luminescent functional metal-organic frameworks, Chem. Rev. 112(2012)1126-1162.

[5]X.M. Hao, C.S. Gu, S.Y. Han, Y.Z. Fan, Y. Li, W.D. Song, Synthesis, crystal structures of Zn(II) and $\mathrm{Mn}(\mathrm{II})$ complexes with flexible sulfur containing aromatic acid and nitrogen heterocyclic ligands, Chin. J. Inorg. Chem. 31(2015)369-376.

[6]B.L. Chen, N.W. Ockwig, A.R. Millward, D.S. Contreras, O.M. Yaghi, High $\mathrm{H}_{2}$ adsorption in a microporous metal-organic framework with open metal sites, Angew. Chem. Int. Ed. 44(2005)4745-4749.

[7]S.Yang, X. Lin, A.J. Blake, K.M. Thomas, P. Hubberstey, N.R. Champness, M. Schröder, Enhancement of $\mathrm{H}_{2}$ adsorption in $\mathrm{Li}^{+}$-exchanged coordination framework materials, Chem. Commun. (2008)6108-6110.

[8]X.M. Hao, G. Chen, C.S. Gu, J.W. Liu, Poly[ $\mu 7$-sulfanediyldiacetato-disilver(I)], Acta Cryst C. 69(2013)826-828.

[9]J. Xie, Y.Q. Huang, T.A. Okamura, W.Y. Sun, N. Ueyama, Anion effect on structure of silver(I) complexes with new unsymmetrical tripodal ligand, Z. Anorg. Allg. Chem. 633(2007)1211-1216. 
[10]X.M. Hao, G. Chen, C.S. Gu, A new two-dimensional silver coordination polymer constructed by 1,3-bis(4-pyridyl)propane and 2,6-dichlorophenylacetic acid: synthesis, structure, luminescence and thermal stable properties, Asian. J. Chem. 26(2014)5805-5808.

[11]C.S. Gu, X.M. Hao, S.X. Guan, J.W. Liu, Poly[[ $\mu$-aqua-bis $(\mu-2,4-$ dichlorophenoxyacetato)barium(II)] monohydrate]. Acta Cryst C. 62(2006)516-518.

[12]S.M. Shi, Z.F. Chen, Y.C. Liu, L. Mao, H. Liang, Z.Y. Zhou, Synthesis and crystal structures of lanthanide complexes with foliage growth regulator: phenoxyalkanoic acid, J. Coord. Chem. 61(2008) 2725-2734.

[13]J.H. Liao, S.H. Cheng, C.T. Su, Synthesis, characterization and sorption properties of a porous coordination polymer: $\mathrm{Co}_{3}$ (citrate $)_{2}\left(4,4^{\prime} \text {-bipyridine }\right)_{4}\left(\mathrm{H}_{2} \mathrm{O}\right)_{2} \cdot 4\left(\mathrm{H}_{2} \mathrm{O}\right)$, Inorg.Chem.Commun. 5(2002) 761-764.

[14]X.J. Liu, Q.R. Fang, G.S. Zhu, M. Xu, X. Shi, G. Wu, G. Tian, S.L. Qiu, L. Fang, Crystal structure and fluorescence of a novel 3D inorganic-organic hybrid polymer with mixed ligands, Inorg.Chem.Commun. 7(2004)31-34.

[15]S. Gao, J.W. Liu, L.H. Huo, Y.M. Xu, H. Zhao, A two-dimensional Cd(II) coordination polymer: [Cd(1,4-BDOA)(1,10-phen)] $\mathrm{H}_{2} \mathrm{O}$ with strong blue fluorescent emission constructed by benzene-1,4-dioxydiacetate ligand, Inorg.Chem.Commun. 8(2005)361-364.

[16]X.M. Hao, C.S. Gu, L.L. Li, S.J. Li, Y. Li, W.D. Song, Syntheses and crystal structures of two $\operatorname{Ag}(\mathrm{I})$ complexes with 2,4-dichlorophenoxyacetic acid and nitrogen heterocyclic ligands, Chin. J. Inorg. Chem. 31(2015)1063-1070.

[17]X.M. Hao, C.S. Gu, S. Y. Han, Y.Z. Fan, Y. Li, W.D. Song, Synthesis, crystal structures of Zn(II) and $\mathrm{Mn}$ (II) complexes with flexible sulfur containing aromatic acid and nitrogen heterocyclic ligands, Chin. J. Inorg. Chem. 31(2015)369-376. 